\title{
Development of Thermal Functional Fibers with Heat of Wetting Part 2 : Exothermic Mechanism of Heat of Wetting on Wool Fibers
}

\author{
Kiyoichi Matsumoto*, Yoshinobu Ogawa*, \\ Tomohiro Nojiri**, Yumiko Izumi*** and Hiroyuki Uejima****
}

\begin{abstract}
In this report, the exothermic mechanism of wool fibers by adsorbing moisture is discussed in detail based on thermodynamics. The following results are :

(1) Hygroscopic and exothermic value of wool fibers at the moisture adsorption were measured simultaneously, and it was confirmed that a large amount of heat on wool fibers generated at the initial stage of moisture adsorption.

(2) Moreover, a weight change in connection with thermal variation of wool fibers in hygroscopic adsorption time were measured at the same time. It is suggested that the water molecules in wool fibers are adhering to protein molecules in a clustered state when the fibers generate the heat by moisture adsorption.

(3) In the results of measurement for exothermic heat of wetting in relation to change of temperature, it was clarified that the contribution of three hydrophilic groups $\left(-\mathrm{NH}_{2},-\mathrm{OH}\right.$, and $\left.-\mathrm{COOH}\right)$ in keratin on heat of adsorption depended on the environmental temperature.
\end{abstract}

Key Words : Wool Fiber, Heat of Wetting, Hygroscopic Adsorption, Thermodynamics, Exothermic Mechanism.

(Received July 31, 1997)

(Accepted for Publication May 11, 1999)

\section{湿潤発熱機能性繊維の開発}

\section{（第 2 報）毛繊維の湿潤熱の発生機構}

松本喜代一*, 小川 宜伸*, 野尻 智弘**, 泉 由美子***, 植嶋 宏元****

\section{1. 緒 言}

前報1)で, カシミヤ繊維を中心に各種繊維の湿潤 熱を熱分析して, 特に羊毛タンパク質中に存在する 各種の親水性官能基が湿潤熱の発生に著しく影響す ること，およびアミノ基の寄与が比較的重要である ことがわかり, 新規な湿潤発熱機能性繊維の開発研 究に際して有力，かつ有効な情報を得ることができ た.
本報告では, 前報に引き続いて, 毛繊維内の吸着 水分の分子状態における湿潤発熱機構を熱力学的に 解釈して詳細に検討する. まず, 毛繊維の湿潤時に おける湿度と発生熱の同時測定によって湿潤発熱の 経時変化を調査して発熱量の時間分布状態から測定 時間の妥当性を確認する. 次に, 湿潤発熱過程にお ける熱的変化と重量変化を同時測定して, 湿潤発熱 時に羊毛分子内に吸着した水分子の存在状態を熱力 学的立場から解明する. そして, 新規な織維の用途

*Member, formerly Faculty of Textile Science, Kyoto Institute of Technology, Kyoto, Japan, 会員, 元京都工芸緎維大学紻維学 部, 京都市左京区松ヶ崎, **Industrial Technical Center of Toyama, 富山県工業技術センター織維研究所, 富山県東研波郡福野町 $* * *$ Member, Kacho Junior Collage, 会員, 華頂短期大学, 京都市東山区林下町 3-1, **** Member, Shiga Perfectural University, 会員, 滋賀県立大学, 彦根市八坂町 
開発の立場から35から50Cについての毛織維の湿潤 による発熱量を測定して, 温度変化に伴う 3 種類の 親水性基の発熱に対する影響を検討して，新規な湿 潤発熱機能性織維の開発のための基礎的研究の一つ とする.

\section{2. 実 験}

\section{1 測定試料およひ試薬}

測定試料には精製したカシミヤ緎維を用いた，試 料は前報と同様に, ジェチルエーテルで洗浄し, 次 いで水で洗浄し, 乾燥の後, 裁断して真空デシヶー 夕中に保存して测定に供した。

湿潤熱発生に対する試料中の官能基の影響を調べ るための化学修飾用および分析用試薬もまた, 前報 と同様に, 市販特級薬品をそのまま使用した.

\section{2 測定装圈}

湿潤熱の测定には, 島津示差熱量計 DSC-50(以 下DSC と略）を用いた. DSC セル内の湿度調整法 は，前報のとおりである.

一方, 湿潣時の熱的重量変化の同時測定には，島 津 TG-30型熱重量測定装置（以下 TG と略）を用い た.

\section{3 湿潤熱の測定法および解析法}

湿閵熱は, 前報と同様の方法で, 絶乾試料につい て35 50 ${ }^{\circ} \mathrm{C}$ で测定し, 前報と同様の方法によって温 度変化に伴う親水性基の影響を調查した。

一方, 湿度変化に伴い発生する湿潤熱之重量変化 の同時測定は, カシミヤ試料約 $5 \mathrm{mg}$ を用いて, 堂素 ガス雾囲気中で昇蕰速度 $10^{\circ} \mathrm{C} / \mathrm{min}$ で行った.

\section{4 化学毫飾試料の調製}

カシミヤ試料の湿潤熱に及ぼす親水性基の影響を 検討するためには, 前報と同様に, 試料をメチルエ ステル化，あるいはアセチル化による化学修飾を行 って, それらの反応度の異なる武料について湿閏熱 の発生を熱分析した．これらの試料の反応生成物 は, 前報と同様に, 常法の官能基量の定量分析およ び $\mathrm{KBr}$ 錠剤法による赤外 (IR) スペクトル测定によ って分析した.

\section{3. 結果亡考察}

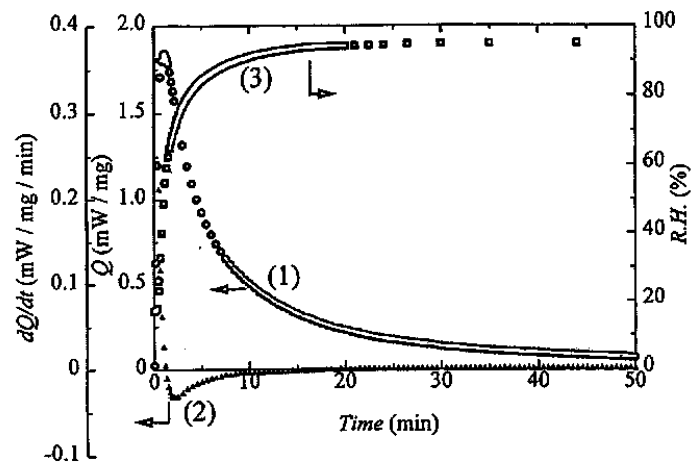

Fig. 1 Curves in case of simultanous measurement of humidity and the heat of wetting.

\section{1 毛紼維の湿润時における湿度と発生熱の 同時測定}

試料カシミヤの湿潤熱について, 所定睄定温度に おける湿度変化に伴う発熱量の経時変化の測定結果 のうち， $40^{\circ} \mathrm{C}$ における代表例を Fig.1 に示す。この 結果から DSC セル内を時間 $\mathrm{T}=0$ で湿度調節用の 窒素ガス流を止めると，試料瀻維は曲線（3）のよう な環境湿度の上昇に伴って曲線 (1)のように湿濶初 期に急激に大量に発熱し，その後，緩やかな発熱過 程を経て, やがて発熱が終わり, 平衡に到達してい ることがわかる，そのときの dQ/dt曲線 (2) は, 約 $10 \mathrm{~min}$ 以降では $0(\mathrm{~mW} / \mathrm{mg} / \mathrm{min})$ であり, 発熱が 終わっていることを示し，湿潤時における発熱過程 の様子をより明確に示している. なお，この場合の 発熱量は, 前報で述べたように, DSC 曲線と発熱後 のベースラインが囲む面積から求めた。

\section{2 湿潤発熱過程の熱力学的解釈}

湿潤発熱過程をさらに詳細に調查するために, TGを用いて試料の湿㵎に伴う示差熱と重量変化を

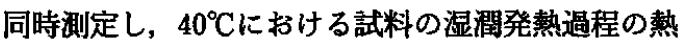
的および重量変化のデータを Fig.2に示す. セル内 の湿潤源が乾嬠してしまう時間の関係から飽和時ま での測定ができなかったために，発熱曲線の減衰部 分および重量変化曲線について, 指数関係型の近似 をして求めた補外値を飽和値としてべースラインを 補正した，得られた補正曲線（Fig.3）功単位時間 における発熱量を求め, 水分子 $1 \mathrm{~mol}$ 当たりの発熱 量を算出した。これらの檤を測定時間についてプロ ットして Fig.4 に示す.これによって単位水分当た りの吸着熱は, 吸湿開始後, 約 $5 \mathrm{~min}$ でほぼ一定に 


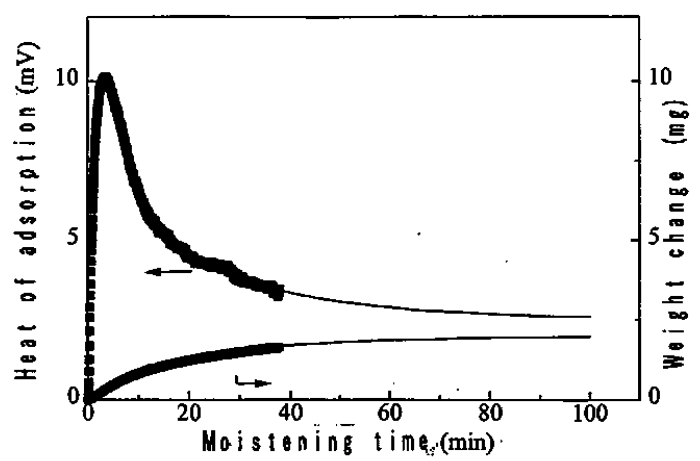

Fig. 2 TGA curves of the heat of adsorption and the weight changes about the moistening time. Upper line; DSC curve, lower line; gravimetric curve.

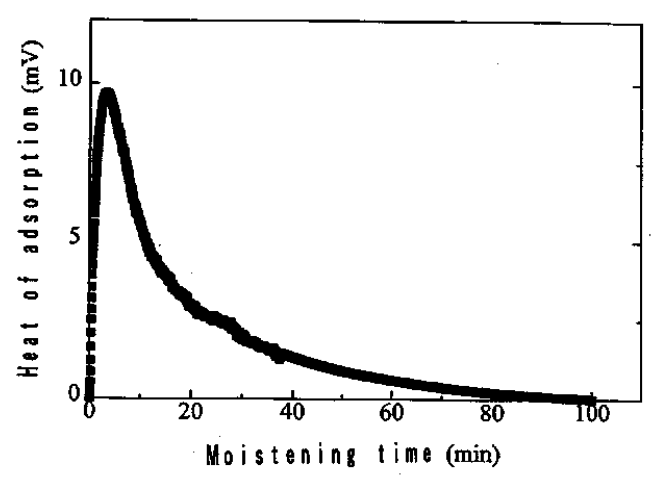

Fig. 3 TGA curve obtained by correcting base line of gravimetric curve in Fig. 2.

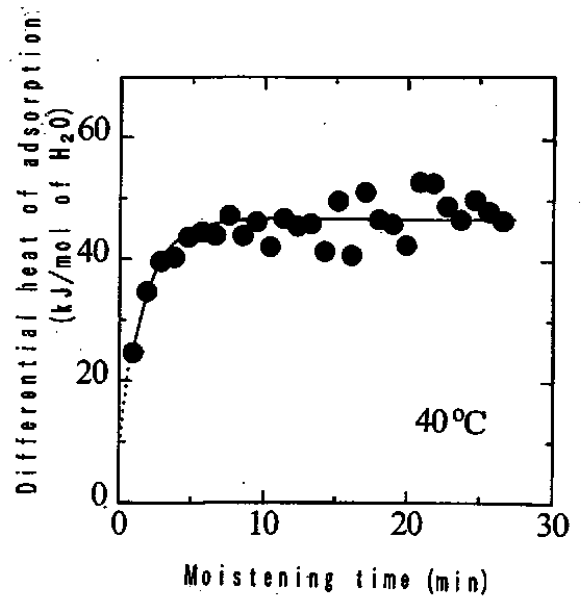

Fig. 4 Graph calculated quantity for the differential heat of adsorption in the plot about the measurement time.

なることがわかる.この值は, 水の蒸発熱である約 $44(\mathrm{KJ} / \mathrm{mol})$ の値と一致する, 従って, この時間に
おいて発生した吸着熱の大部分は水の凝縮熱であ り,この過程で吸着された水分子の大部分は瀻維内 で分子状のクラスターとして液相状態で存在してい ることが示唆される. また, この曲線の $\mathrm{T}=0$ への 外挿値は約 $10(\mathrm{KJ} / \mathrm{mol}$ of water) であり, 水分子の 織維への単分子吸着熱の妥当な值を与えている.

ここでカルボキシル基の水和熱について,

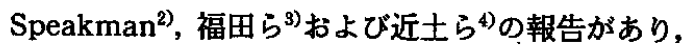
また, カルボキシル基に吸着する水分子の数は, Watt ら5) が80\%RH で2.5と報告しているので，こ れらの值を用いてカルボキシル基 $1 \mathrm{~mol}$ に対する水 分子 $1 \mathrm{~mol}$ 当たりの発熱量を計算した，それをまと めたのが Table1 である. 上述の示差熱重量同時測 定から求めた水分子の瀻維への単分子吸着熱の值, 約 $10(\mathrm{KJ} / \mathrm{mol}$ of water) は, これら 3 者のデータの 範囲内にある. 従って,この結果は本方法が吸着熱 研究の有力な手法の 1 つになることを示唆してい る.

\section{3 湿閏熱に及ぼす毛綞稚分子内の吸渞水分 子の状態}

毛織維に限らず一般に高分子中の水分子の状態 は, その化学構造および温度と湿度に依存する水分 子の活性の両者に支配されて共同運動しながら， ミ クロ状態 $\left[\mathrm{X} \cdots(\mathrm{H}-\mathrm{O}-\mathrm{H})_{\mathrm{n}} \cdots \mathrm{Y}\right]$ で変化すると考え られている. しかし, 高分子種や水分子の活性によ って変化するクラスターサイズなどについては，い まだ不明な点が多く, 今後の分子レベルでの研究が 期待されている6).

そこでまず，湿潤熱に及ぼす毛瀻維分子内の吸着 水分子の存在位置と結合状態を考察する. 前報でも 述べたように, 湿潤熱発生の主な原因は, 試料毛織 維中の官能基と水分子との間での二次的な結合（水 素結合）の生成である. 水と親和性のある官能基は 親水性基であり，羊毛ヶラチン中のそれは主鎖のぺ プチド基のほかに，㑡鎖のアミノ基，カルボキシル 基および水酸基の 3 種類の官能基によって占められ ていることがアミノ酸分析の結果によって, 従来か ら知られている. 湿潤熱に及ぼす毛䄉維分子内にお ける吸着水分子は, 毛絨維を構成する高分子鎖中の これらの親水性基を介して水索結合している，その ことは, 官能基の化学修飾による湿潤熱の変化を測 定した結果から容易に理解できることを前報ですで に述べた，しかし，この水分子が 3 種類の親水性基 を介して, どのように結合しているかは，大变興味 
Table 1 Energy of hydration for-COO-group and energy of bonding between $\mathrm{H}_{2} \mathrm{O}$ on -COO-group.

\begin{tabular}{cc}
\hline $\begin{array}{c}\text { Energy of hydration } a \\
\left(\mathrm{kcal} / \mathrm{mol} \text { of }-\mathrm{COO}^{-}\right)\end{array}$ & $\begin{array}{c}\text { Energy of bonding between } \mathrm{H}_{2} \mathrm{O} \text { and }-\mathrm{COO}^{-} \text {group } b \\
\left(\mathrm{~kJ} / \mathrm{mol} \text { of }-\mathrm{COO}-\text { group and } \mathrm{H}_{2} \mathrm{O}\right)\end{array}$ \\
\hline 7.4(Speakman) & 12.4 \\
9.1 (Fukuda et.al.) & 15.2 \\
5.25 (Kondo) & 8.76 \\
\hline
\end{tabular}

* $" b "$ is calculated from the data " $a$ " and 2.5 water molecules on $-\mathrm{COO}^{-}$

by Watt et.al. by using the following formula : $a \times 4.18 \div 2.5$.

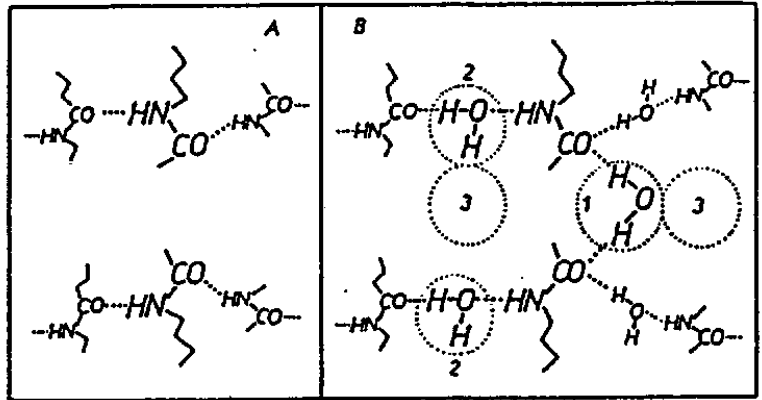

Fig. 5 Model of displacement of adsorbed water in Nylon-6 which Puffr presented. A: Dry amorphous Nylon. B : Wet state at saturated vapor pressure ; 1, firmly bound water, 2, lossely bound water, 3 , site for capillary condensed water.

のあることである.

ここでは, 羊毛ケラチン主鎖中のペプチド結合 ($\mathrm{CO}-\mathrm{NH}-)$ について，それと同様のアミド結合（$\mathrm{CO}-\mathrm{NH}-$ ) を有するポリアミドへの水分子の吸着機 構に関するPuffr らの研究》を参考にして考察す る. 彼らは, 彼ら自身のデータを基にして多くの公 表されたデータを加えて, 線状ポリアミド中の水の 吸着機構に関して種々の方法で詳細に検討している (Fig.5). すなわち，ナイロン6について，むし毛細 管凝縮した水を考慮に入れないのならば，室温の 1 個の水の活性度を 1 として，吸着中心ではたかだか 3 個の水分子によって占められるであろう，第 1 番 目の水分子 $(\mathrm{H}-\mathrm{O}-\mathrm{H})$ は, 酸素原子上の自由電子対 によって 2 個のカルボニル基 (-CO-) との間に二重 結合を形成して，この段階において多量の熱が放出 される，この水は強固に結合した低活性度の水と考 えられる. あと 2 個の水分子は無視し得る程度の熱 効果しかなく，カルボニル基と水素原子との間のす でに存在している水素結合に加わり，緩く結合した 水として区分されるであろう，そして，水の単一層 への優先的な吸着は, それらの中で 3 個の水分子が 2 個のアミノ基に吸着される.しかしながら，付加
的な水がカルボニル基とアミノ基との間に吸着され るか，あるいは単一首の既存の吸着水の酸素に吸着 されるかを決定することは不可能である．なお，緇 維中の親水性基と水分子の間で生じた熱に加えて, 複数の水分子がちょうどブドウの房状のようなクラ スター状態に集合した水分子間の相互作用に起因し て発生する熱むまた大きいであろうと述べている.

我々は, 毛㵶維の水吸着機構と湿潤発熱の関連に ついても,この Puffr らの提出したポリアミドの水 吸着機構モデルを支持し, 化学構造的および物理化 学的な解釈に基づいて, 同様の機構で水が吸着し て, この水が湿潤時の発熱に直接関与していると考 える．その上，さらに毛紻維分子に直接水素結合で きなかった水分子は, 赤外的研究や核磁気共鳴 （NMR）による研究によって明らかにされているよ うに, 毛瀻維のような親水性高分子では複数個の水 分子が会合して形成してクラスター状態で吸着して いると考えるのが合理的であろう。また，これから あ吸着した水が液体状態で凝縮しているよりあ水蒸 気中に単分子で存在して吸着した方が大きいという 両者間の発熱量の差の原因として良く理解できよ う. 


\section{4 体温近傍温度での湿潤熱への官能基の影 響}

毛䋞維の湿潤発熱の衣服などへの用途を考慮に入

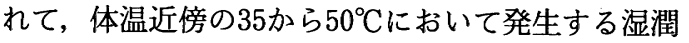
熱を前報と同様に, 試料カシミャを化学修飾して各 官能基ごとの湿潤熱を測定して Fig.6 に示す. 測定 した環境温度範囲内において, 発熱に関与する 3 種 類の親水性基の影響は，いずれもほぼ直線的な相関 関係を示した. 湿潤熱発生に関与する 3 種類の親水 性基個々については, 低温側ではアミノ基とカルボ キシル基の寄与が比較的大きく, 昇温に伴いアミ, 基の寄与はわずかに増加するのに反して，カルボキ シル基のそれは若干低下する。これらは，たとえ 3 個の水分子がクラスター状態で吸着していてあエネ ルギー的に安定であると考えられる. しかし，水酸 基の寄与は，低温側ではかなり少ないけれども昇温 に伴って著しく増大することがわかる．毛織維分子 の親水性基に吸着し水素結合した水分子は, $35^{\circ} \mathrm{C}$ ら50 ${ }^{\circ} \mathrm{C}$ への昇温に伴い分子全体の熱運動が活発化す るとき, 3 種類の内の水酸基を介している水素結合 は，他の親水性基と介しているよりも結合エネルギ 一的に緩い結合状態であってあ活性度が高くなり離 脱しやすく，湿潤によって生成していた吸着熱を多 く放出することを示唆している.

古く Leeder $ら^{8)}$ によれば, 羊毛ヶラチン中での 水の吸着によるアミノ基の役割は水分含有量によっ て異なり, 高湿度ではアミノ基への $2 \sim 3$ 個の水分 子が, 水分増加に伴って Langmuir の等温吸着則か ら逸脱し，より高湿度になると水は付加的な吸着も 起こることを熱力学的に証明している. タンパク質

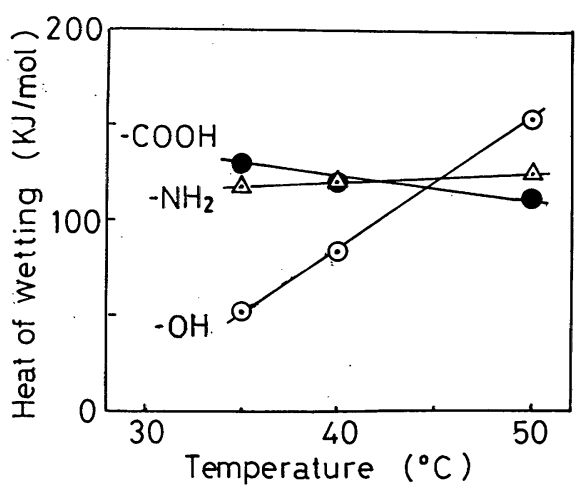

Fig. 6 Heat of watting of hydrophilic groups in cashmere at different temperature.
中のアミノ基への水の付加は, 他の親水性基の場合 よりあ高い結合ェネルギーを伴って起こるので，こ のアミノ基の改質は他の基よりも大きい影響を与え るであろうと示唆している. このように, 湿潤熱発 生においてアミノ基の寄与が大きいことは, 前報に おいて, タンパク質系繊維の方がセルロース系繊維 よりあ発生する湿潤熱が大きいという結果からあ理 解することができる. しかし，この Leeder らの示 唆は, 我々の研究結果では $40^{\circ} \mathrm{C}$ 以下の比較的低温に

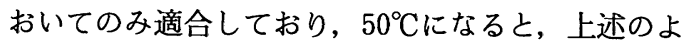
うに, 3 種類の官能基の内で水酸基の湿潤熱発生へ の寄与が著しく増大して, アミノ基やカルボキシル 基両者が発生する湿潤熱を圧倒しており, 単純に適 合しないように思われるので, さらに今後の検討に 待ちたい.

\section{4. 結 言}

新規な湿潤発熱機能性繊維の開発研究の基礎とす るために, 前報に引き続いて毛緘維の湿潤熱の発生 機構を詳細に解明することを試みた。 その結果, 次 のような成果があった。

（1）毛繊維の湿潤時における湿度と発生熱の同 時測定の結果から，湿潤初期に急速に大量に発熱 し，約10min で終了することがわかった。

（2）さらにまた，湿潤発熱過程における熱的変 化および重量変化の同時測定の結果から, 湿潤発熱 時における毛繊維分子内に吸着した水分子の存在状 態を解釈することができた。

（3）体温近傍の温度における毛繊維の湿潤熱の 測定結果から, 羊毛ケラチン中の 3 種類の親水性基 の寄与が環境温度によって異なることがわかった。

（謝 辞）本研究の遂行に際して, 試料提供と懇 切なご指導・ご討議をしていただいた元・京都大学 近土隆教授, 京都大学化学研究所宮本武明教授およ びご協力・ご討論していただいた京都工芸繊維大学 繊維学部, 故 - 内海暢生教授, 清造剛教授, 堤直人 博士に厚くお礼申し上げます。

（追 記） 本研究の一部は, 繊維学会平成 4 年度 年次大会(' 92.6. 東京) 及び日本繊維機械学会第 49 回年次大会（'96.6. 大阪）にて口頭発表した.

\section{参考文献 (References)}

1) K. Matsumoto, Wu Ying, Y. Izumi \& H. Uejima; J. Text. 
Mach. Soc. Japan (Japanese Ed.), 52, T105 (1999)

2) J. B. Speakman ; Trans. Faraday Soc. , 40, 6-10 (1944),

3) M. Fukuda, K. Ohtani, M. Iwasaki \& H. Kawai ; Sen-i Gakkaishi, 43, 567 (1987)

4) T. Kondo: J. Text. Mach. Soc. Japan (Japanese Ed.), 38,
32 (1985)

5) I. C. Watt \& J. D. Leeder ; J. Appl. Chem. , 18, 1 (1968)

6) H. Kusanagi ; High Polymer, Japan, 42, 314 (1993)

.7) R. Puffr \& J. Sebenda; J. Polymer Sci. , C-16, 79 (1967)

8) J. D. Leeder \& I. C. Watt ; J. Phys. Chem. , 69, 3280 (1965)

\section{繊維機械学会論文集投稿規定}

\section{1. 投稿資格}

原稿の著書は日本繊維機械学会会員に限る。連名の場 合は少なくとす 1 名が同会員でなければならない。ただ し, 編集委員会が特に認めたすのについてはこの限りで はない。

\section{2. 投稿原稿の種類}

\section{1 論 文 (Original Paper)}

繊維に関連する科学, 工学, 技術に関する未刊行の創 意ある基礎的並びに応用的な報文で, 新しい価値ある結 論又は事実を得ているもの. 原稿の長さは原則として刷 り上がり 6 頁以内とする.

\section{2 技術報告 (Technical Report)}

工業的に役立ち，技術的に価值を有する試験，実験， 調查等に関する結果の報告で未刊行のもの. 原稿の長さ は原則として刷り上がり 6 頁以内とする.

\section{3 速 報 (Letter)}

論文と同様の未刊行の内容であるが, 理論, 実験, 技 術における新しい進歩を速報するもので, 将来において 充実した内容の論文に完成させることを前提としたも の. 原稿の長さは原則として刷り上がり 4 頁以内とす る.

\section{4 コメント (Comment)}

論文等の内容に関する質問ないし関連する意見および 原著者の回答等に関するあの. 原稿の長さは原則として 刷り上がり 3 頁以内とする.

\section{3. 投稿手続きおよび審査}

原稿は織維機械学会論文集執筆要綱に適合している のであること．投稿申込用紙，図，表および原稿ととあ にそれらのコピー2 部（速報およびコメントは 1 部）を 添えて, 瀻維機械学会論文集編集委員会 (550-0004/大 阪市西区勒本町 1-8-4, 大阪科学技術センタービル内, 日本繊維機械学会, 電話06-6443-4691)宛に投稿する. 原 稿の受理日は本学会到着の日とする.

投稿原稿の審查の結果, 原稿の訂正または著者の見解 を求めることがある. この場合, 編集委員会から送付さ れた日付より 3 か月以内に返送されない場合は取り下げ たものとして処理される.

\section{4. 別刷および制限頁数の超過}

別刷は有料とし，下表に従って最低100部は購入しな ければならない。

\begin{tabular}{c|c|c}
\hline 刷上ページ数 & $1 \sim 4$ & $5 \sim 6$ \\
\hline 100 部の料金 & 25,000 円 & 30,000 円 \\
\hline
\end{tabular}

6 頁以上の別刷代は 2 頁増加するごとに 30,000 円を加 算する.

10頁を超える制限頁数の超過については, 1 頁を超過 するごとに 15,000 円を徵収する.

100部以上の別刷を希望される場合は，著者校正を返 送する際に申し込むあのとし, 別に定める料金表に従っ て費用を徵収する. 